University of South Carolina

Scholar Commons

$10-1983$

\title{
Teaching Behavior through Various Levels of Field Experiences
}

J. Len Gusthart

University of Saskatchewan

Judith E. Rink

University of South Carolina - Columbia, jrink@mailbox.sc.edu

Follow this and additional works at: https://scholarcommons.sc.edu/pedu_facpub

Part of the Education Commons

\section{Publication Info}

Published in Journal of Teaching in Physical Education, Volume 3, Issue 1, 1983, pages 32-46.

http://journals.humankinetics.com/jtpe-contents

(C) 1983 by Human Kinetics Publishers, Inc.

This Article is brought to you by the Physical Education, Department of at Scholar Commons. It has been accepted for inclusion in Faculty Publications by an authorized administrator of Scholar Commons. For more information, please contact digres@mailbox.sc.edu. 


\title{
Teaching Behavior through Various Levels of Field Experiences
}

\author{
J.L. Gusthart \\ University of Saskatchewan \\ and \\ Judith Rink \\ University of South Carolina
}

Many colleges of education across North America recently have redesigned their teacher education programs. One trend has been the extension of field-based experiences. Yet, the lengthening of contact time between potential teachers and pupils is, in itself, no assurance of improving the preparation of teachers. Faculties of education must be prepared to develop quality assessment procedures to ascertain the effectiveness of program designs, particularly as they become more and more concerned with field-based experiences that tend to drain the resources of an institution.

The elementary school physical education teacher preparation program at Bowling Green State University, Bowling Green, Ohio has received national attention by the American Association of Colleges of Education for Teacher Education. In 1977, an Award of Merit was presented to Bowling Green for its excellence in teacher education. A large part of this program is devoted to extensive teaching experiences out in the schools. Five levels of field-based experiences were identified for this study. Many studies, particularly at the Ohio State University have documented the positive effects of intervention strategies on the teaching behavior of pre-service teachers (Siedentop, 1981). Little has been done to trace the development of teaching behavior through a field-based program. The intent of this study was to describe the continuous development of pre-service teacher behavior of Bowling Green State University students over a two-year period.

Information on how teaching behavior develops through sequential field-based experiences can provide needed insights into how to design and structure these programs. As the use of field-based experiences becomes more frequent in teacher education programs, the need to evaluate the effects of these programs becomes more important.

The purpose of this study was to describe the instructional behavior of students preparing to be physical education teachers as they progressed through various stages of planned field-based experiences. In addition, an attempt was made to delineate differences in instructional behavior as students advanced through field-based experiences in their undergraduate program.

\section{Procedures}

\section{Subjects}

The subjects $(\mathrm{N}=20)$ were junior and senior physical education majors concentrating in elementary school physical education at the Bowling Green University. Informed consent was obtained from the subjects of the study. The sample represented ninety percent of the available population for the two school years. 
The program for the students in the sample involved an extensive series of methods courses, practicums and student teaching experiences. The students in this study were taught to teach with a movement education orientation to elementary school physical education (Logsdon, Barrett, Braer, McYea, Amonds, Halverson \& Robertson, 1977). Field-based experiences were an integral part of the elementary school physical education curriculum and were required of all students concentrating in elementary school physical education. The college students, in their junior and senior years, had four required courses which focused on practice teaching experiences. In addition, students could elect two field-based teaching experiences.

Monitoring was a key ingredient in the development of the teaching behaviors through the field experiences. College instructors provided close supervision of the preparation of the teaching materials as well as the on-site teaching and evaluation of experiences. Students began their teaching experiences with responsibility for teaching a portion of each lesson to a small group of children once a week. They progressed to full responsibility for several physical education classes per day.

Level One consisted of three lecture hours on campus combined with one field experience per week in an elementary school with both the university professor and the students teaching children. The on-campus instructional time was devoted to studying teaching strategies, planning lessons and critiquing teaching. Interchange among pre-service teachers and feedback from the university instructor highlighted these sessions.

The teaching responsibilities in Level Two were characterized by larger class size groups and increased teaching opportunities for the teacher education student. The students in this experience spent four mornings each week in an elementary school. A college professor was again present at all classes and provided on-site supervision and continued to critique the planning of the preparation of the teaching materials.

Students in Levels Three and Four were assigned to teach one full-sized physical education class in various elementary schools in Bowling Green or Toledo, Ohio. Level Five participants were students enrolled in a full quarter of student teaching. They were given responsibility for teaching physical education to four or more classes from kindergarten through the sixth grade.

The following sequence of field-based experiences was followed by the students in the study. Level Four was an elected experience. All other were required courses. Teaching assignments in Level One and Two were made in a single school where the development of the physical education program was under the direct auspices of the elementary physical education faculty of Bowling Green State University. Teaching assignments in Level Three, Four, and Five were made broadly in a variety of neighborhood schools in Bowling Green and Toledo.

Level 1 - PEP 332 Teaching-Learning Process (four quarter hour credits based on three campus lecture hours and one morning per week in a field-based experience). Teaching Assignment: Groups of two or three university students team teaching seven to nine children ( $1 / 2$ of a class).

Level 2 - PEP 428 The Movement Approach to Teaching Physical Education to Chidren (eight quarter hour credits composed of four half days per week, all field-based experience). PEP 332 is prerequisite. Teaching Assignment: Groups of two or three college students team teaching an entire class.

Level 3 - PEP 387 Junior Practicum Elementary Physical Education (two to four quarter hour credits, all field-based experience). PEP 428 is prerequisite. Teaching Assignment: One student assigned to teach one or two physical education classes.

Level 4 - PEP 487 Senior Practicum Elementary Physical Education (two to four quarter hour credits, all field-based experience), which could be elected prior to or following EDCO 331, Student Teaching. The sample included only those students who registered in PEP 487 prior to student teaching. Teaching 
Assignment: One student assigned to teach one or two physical education classes.

Level 5 - EDCO 331 Student Teaching (fifteen quarter credits, all field-based experience). Teaching Assignment: One student assigned to teach several classes of children.

\section{Data Collection}

An Audio Data Bank Project was initiated in the winter of 1980 and continued for a two year period. Tape recording of lessons was a common procedure in the elementary physical education program. The recording of teacher behavior was used as a learning device and was a natural part of the program. A total of 134 audiotapes were obtained from the student teachers in the five levels of the field-based experience. From this data pool, 20 students with a total of 35 matched pairs of audiotapes were selected for this study. All subjects had both early and late taped lessons at the same course level in the data bank. These two lessons constituted one matched pair for that level. The Observation System for Content Development-Physical Education (OSCD-PE) was used to code the audiotapes (Rink, 1979). The analysis for early and late teaching behavior was combined to provide a single description of each subject for a particular level of field experience. Inter-observer reliability was determined at .82 using percent of agreement on ten randomly selected coded tapes. The tapes were coded independently by each investigator and the results compared. The teaching behaviors of the developing pre-service teachers were described as they progressed through the five levels of field experiences in the elementary school physical education program.

\section{Instrumentation}

The instrument used in analyzing the data in this study was the Observation System for Content Development-Physical Education (OSCD-PE), developed by Rink (1979). Observation System for Content Development-Physical Education is a highly discriminating instrument containing 36 constructs which may be used to describe teacher behavior in physical education. Continuous coding is used to record how teaching behavior functions in terms of the content dimensions of informing, refining, extending and applying and the management dimensions of conduct and organization. The instrument discriminates the use of these behaviors in terms of their relationship to the movement task, the target of behavior and their communication form. A sample observation record is illustrated in Figure 1.

\section{Data Treatment}

The treatment of data took the form of graphic representation for each of the teaching behaviors and constructs. Descriptive statistics, including percents and frequencies, were used to depict instructional behavior. Frequencies were converted to percentages for all constructs. Visual discrimination of all percentage polygons was undertaken to determine trends and differences in teaching behavior.

\section{Results and Discussion}

\section{Communication Function}

There was little change in the communication function of teaching behavior throughout the five levels of field experiences as summarized in Figure 2 (soliciting, responding, initiating, appraising). The overall pattern of behavior described in this study for this function supports earlier descriptive analytic work characterizing physical education as a highly soliciting environment (Morgenegg, 1977). The pedagogical 
I.D. TEACHER A

DATE 4 4/20

CODER 2

DESCRIPTION OF CONTENT THE OVERHEAD PASS (LEG EXTENSION), (PARTNER)

ARRANGEMENT OF EQUIPMENT_INDIVIDUAL BALLS (NERF OR REGULATION)

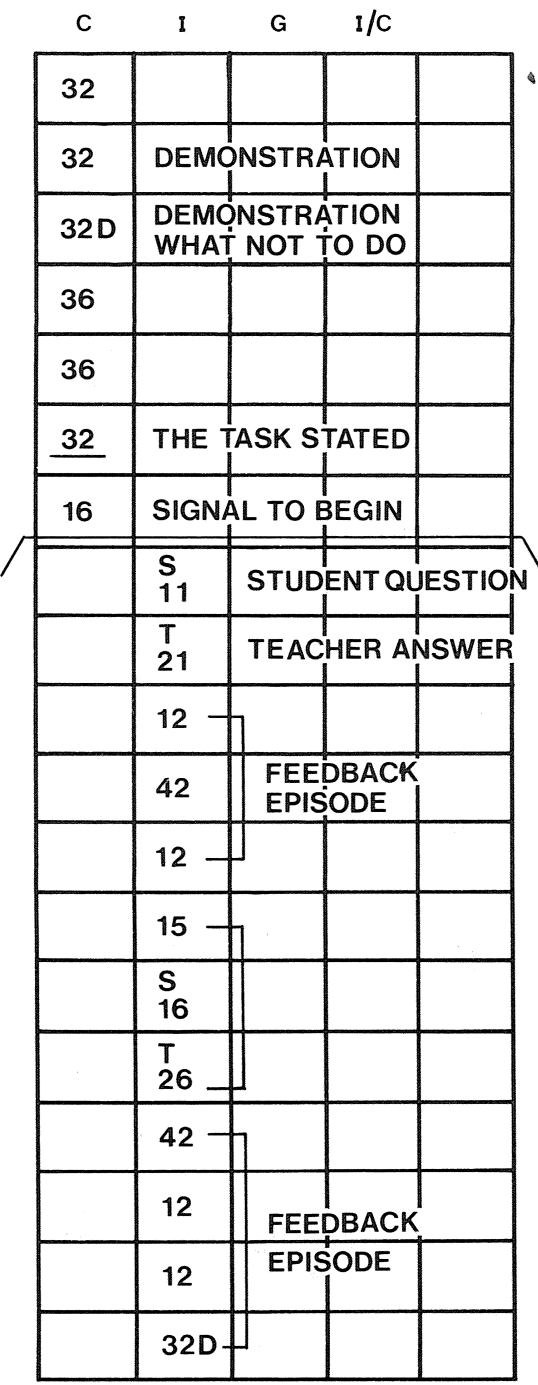
(T) TEACHER
(1) SOLICITING
(S) STUDENT
(2) RESPONDING
(O) OTHER

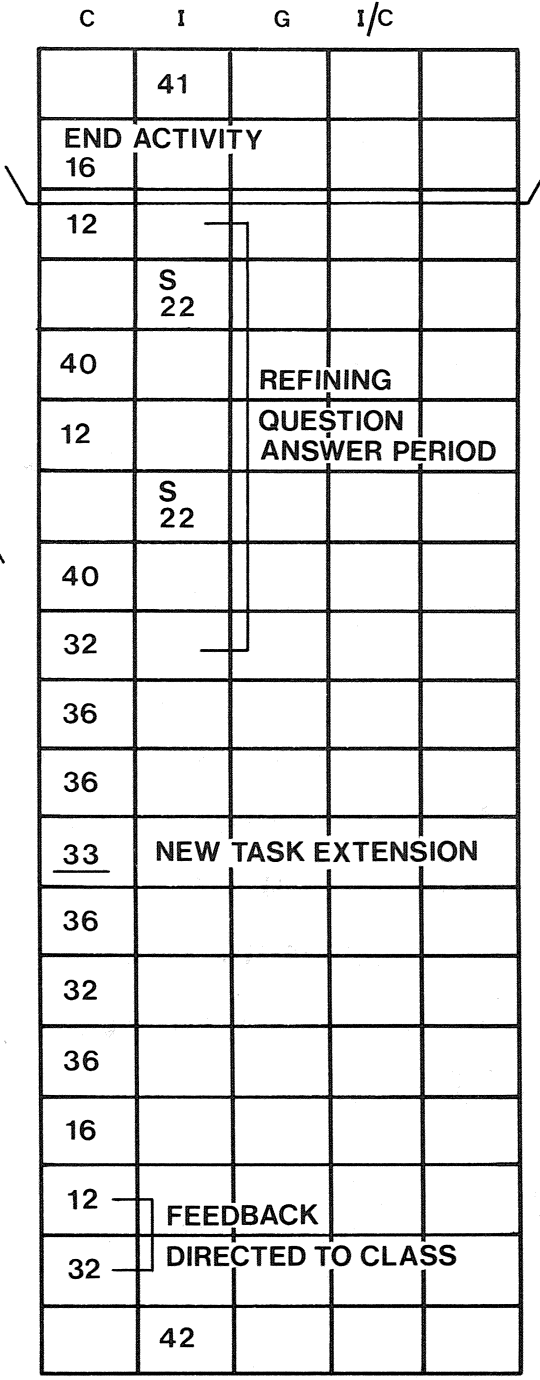

(1) INFORMING

(2) REFINING

(3) EXTENDING

(4) APPLYING

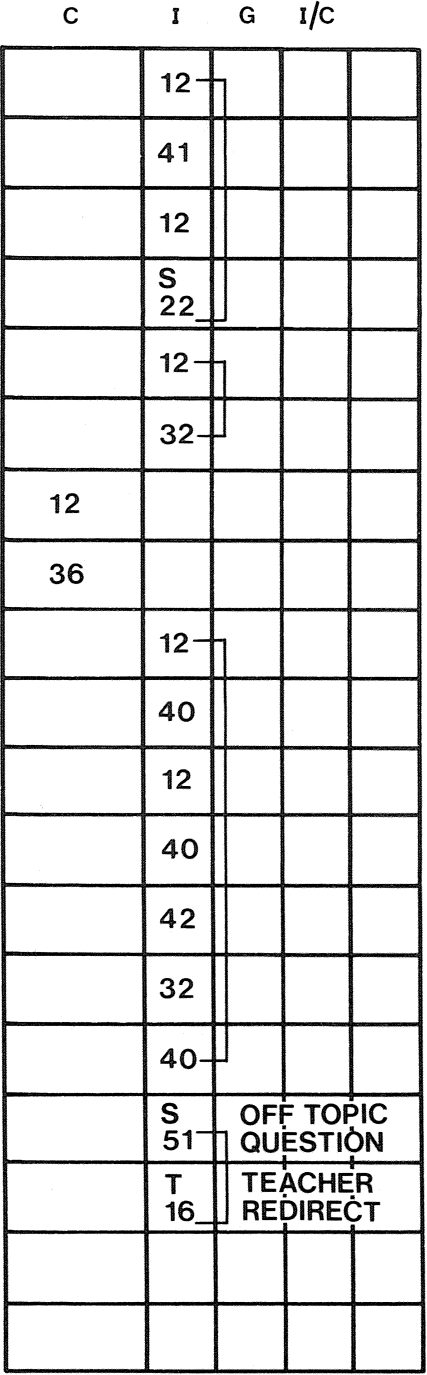

(c) CLASS

(I) INDIVIDUAL

(G) GROUP

( $/ C)$ INDIVIDUAL

(NONPRIVATE)

(51) INDIRECT-OVERT

(5) CONDUCT

(52) INDIRECT-COVERT

(6) ORGANIZATION

(60) NONFUNCTIONING

Figure 1. Sample Observation Record Sheet. 


\section{COMMUNICATION FUNCTIONS}

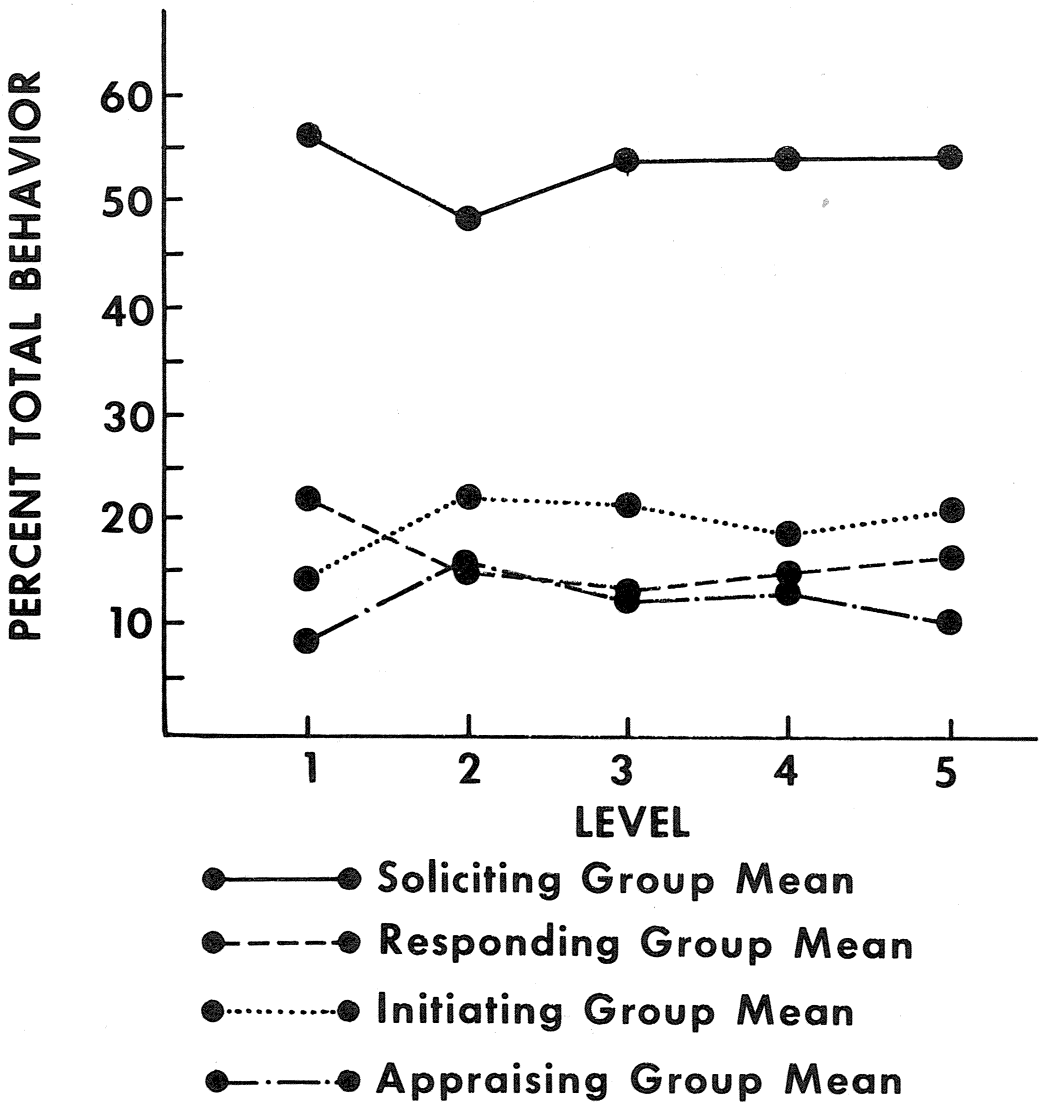

Figure 2. Percent of each Communication Function -- All Tapes.

concepts Morgenegg describes are similar to the communication function of OSCD-PE categories and are contrasted in Table 1. The soliciting and responding categories are defined in a like manner. Morgenegg's structuring category is parallel to the initiating category of OSCD-PE and the reacting category is parallel to the appraising category. The differences in data between the results of Morgenegg and this study are attributable to the specialized teaching orientation of movement education as opposed to Morgenegg's more comprehensive sample.

\section{Design Function}

Directly contributing verbal behaviors are summarized in Tables $2 \mathrm{~A}$ and $2 \mathrm{~B}$ (informing, refining, extending, applying, conduct, organization). Figure 3 illustrates the teaching trends which emerged from the various levels of field experience. There were four types of directly contributing substantive functions of verbal behavior and two managerial functions identified and analyzed in this study. The three verbal behaviors of informing, organizing, and conduct showed an increase from Level One to Level Five. The other three behaviors: refining, extending, and applying, showed a decrease in frequency over the five levels of field experience. 
TABLE 1

Comparison of Morgenegg's Results with

Results of This Study

\begin{tabular}{llll}
\hline $\begin{array}{c}\text { Morgenegg } \\
\text { Category }\end{array}$ & $\begin{array}{c}\text { Results } \\
\text { Percent }\end{array}$ & Category & This Study \\
Structuring & 6.1 & Initiating & 19.0 \\
Soliciting & 43.4 & Soliciting & 54.0 \\
Responding & 32.4 & Responding & 12.0 \\
Reacting & 18.1 & Appraising & 16.0 \\
\hline
\end{tabular}

The decrease in applying teaching behavior (which applies content in a competitıve way) from $7 \%$ to $0 \%$ reflected the subjects intent to devote teaching time to their substantive behaviors. In this study, applying behavior was an infrequent teacher behavior at any of the five levels of the field experiences. It was not a priority for subjects in this sample.

The decline in refining (behaviors which qualitatively seek to improve performance) from $19 \%$ to $7 \%$, and in extending (behaviors which increase or decrease the complexity of difficulty of content) from $15 \%$ to $9 \%$ was not anticipated by the investigators. This drop might have reflected a weak background in the physical education content area, a deficiency in observational skills, or lack of monitoring for these aspects. Although the teacher education students and student teachers demonstrated the ability to plan for both refining and extending behaviors, they did not operationalize this planning. Perhaps a greater emphasis on observational strategies would be useful in bridging the gap between lesson planning and lesson presentation.

A second reason for the decline in refining and extending behavior might be attributed to the increase in the complexity of the teaching environment over the five levels. As the college students progressed through the levels they were given responsibility for a greater number of children which would make it more difficult to attend to the quality of student responses. The increase in class size might have accounted for the increased emphasis on conduct behavior.

Organizational behavior demonstrated only a slight increase (16\% to $19 \%$ ). This was considered to be a positive development. Although the college students were exposed to more complex conditions as they progressed through the various levels, the amount of organizational behavior in relation to other behavior was consistent. Class management time might have been reduced if the pre-service teachers had not organized only to reorganize. 
Gusthart \& Rink

$$
\text { (evers-I - 1-hou/wh fielor eppaciena }
$$

2-4-houlwh"

3-Ju. year field ekpeciense (1-2classes)

$$
4 \text { - SR MTUDENT TeAching }
$$

Means for Constructs Studied ${ }^{1}$

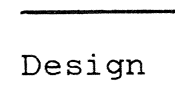

Function
Level

(1)

Level

(2)

\section{Group Means} Level

(3)

Informing
Refining
Extending
Applying
Managerial
Conduct
Organization
TOTAL

Informing
Refining
Extending
Applying
Managerial
Conduct
Organization
TOTAL

Informing
Refining
Extending
Applying
Managerial
Conduct
Organization
TOTAL

Informing
Refining
Extending
Applying
$\frac{\text { Managerial }}{\text { Conduct }}$
Organization
TOTAL

Informing
Refining
Extending
Applying
Managerial
Conduct
Organization
TOTAL
15

7

22

19

5

16

21

100
12

13

24

9

16

26

100

36

Level

(4)

34

16

10

2

14

24

28

100

100

(5)

All Groups

Level

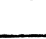

38

31

13

11

4

04

100

100

100

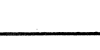

\begin{tabular}{lcccccc} 
Recipient & $\begin{array}{c}\text { Level } \\
(1)\end{array}$ & $\begin{array}{c}\text { Level } \\
(2)\end{array}$ & $\begin{array}{c}\text { Group Means } \\
\text { Level } \\
(3)\end{array}$ & $\begin{array}{c}\text { Level } \\
(4)\end{array}$ & $\begin{array}{c}\text { Level } \\
(5)\end{array}$ & All Groups \\
\hline Class & 33 & 40 & 45 & 49 & 50 & 44 \\
Individual & 18 & 38 & 43 & 45 & 37 & 36 \\
Group & 2 & 13 & 11 & 5 & 10 & 8 \\
$\begin{array}{l}\text { Individual, } \\
\text { Non-private }\end{array}$ & 47 & 9 & 1 & 1 & 3 & 12 \\
$\quad$ Total & 100 & 100 & 100 & 100 & 100 & 100 \\
\hline
\end{tabular}

${ }^{1}$ All data expressed as percents. 
TABLE 2B

Means for Constructs Studied ${ }^{1}$

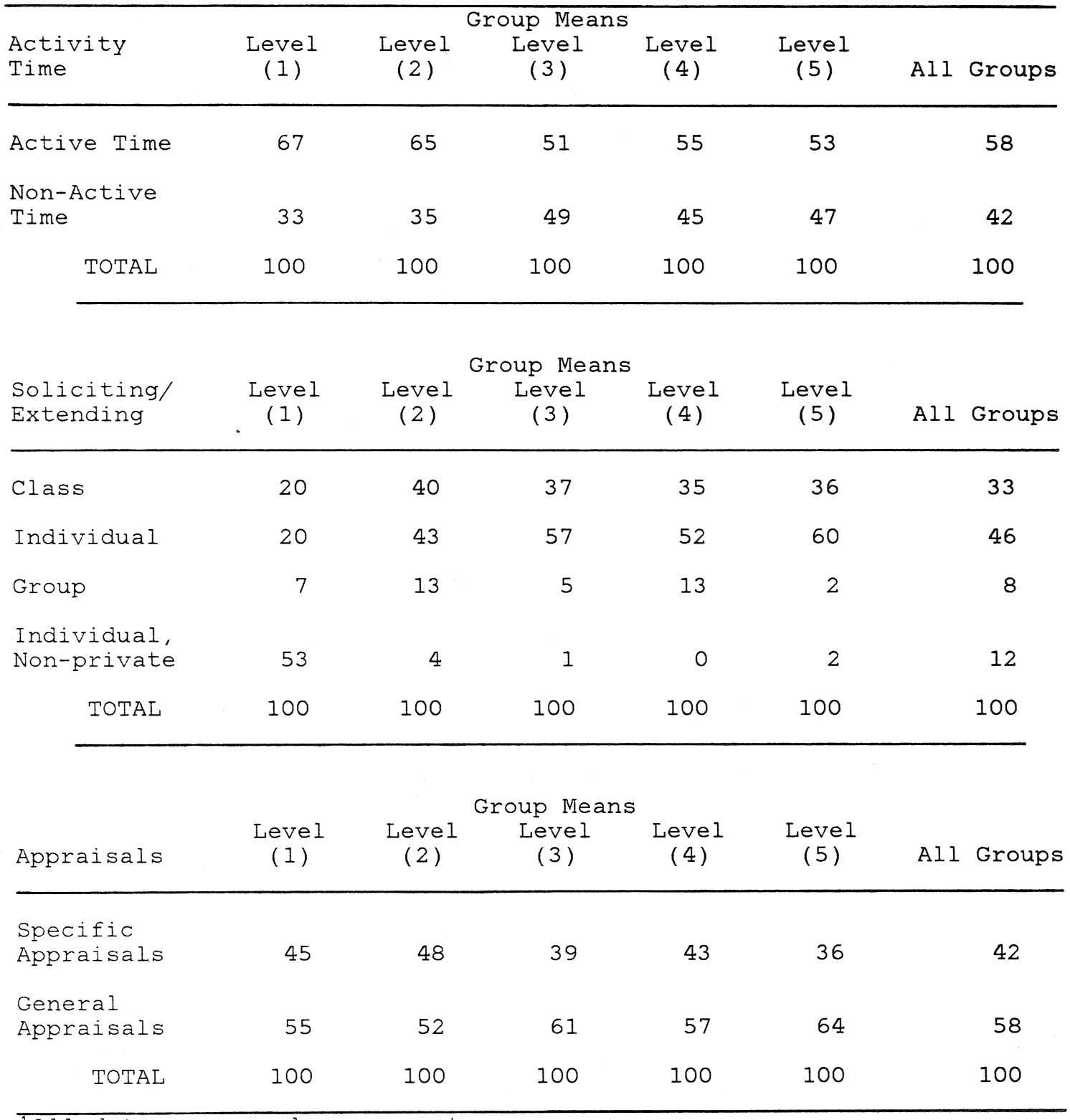

${ }^{1}$ All data expressed as percents. 


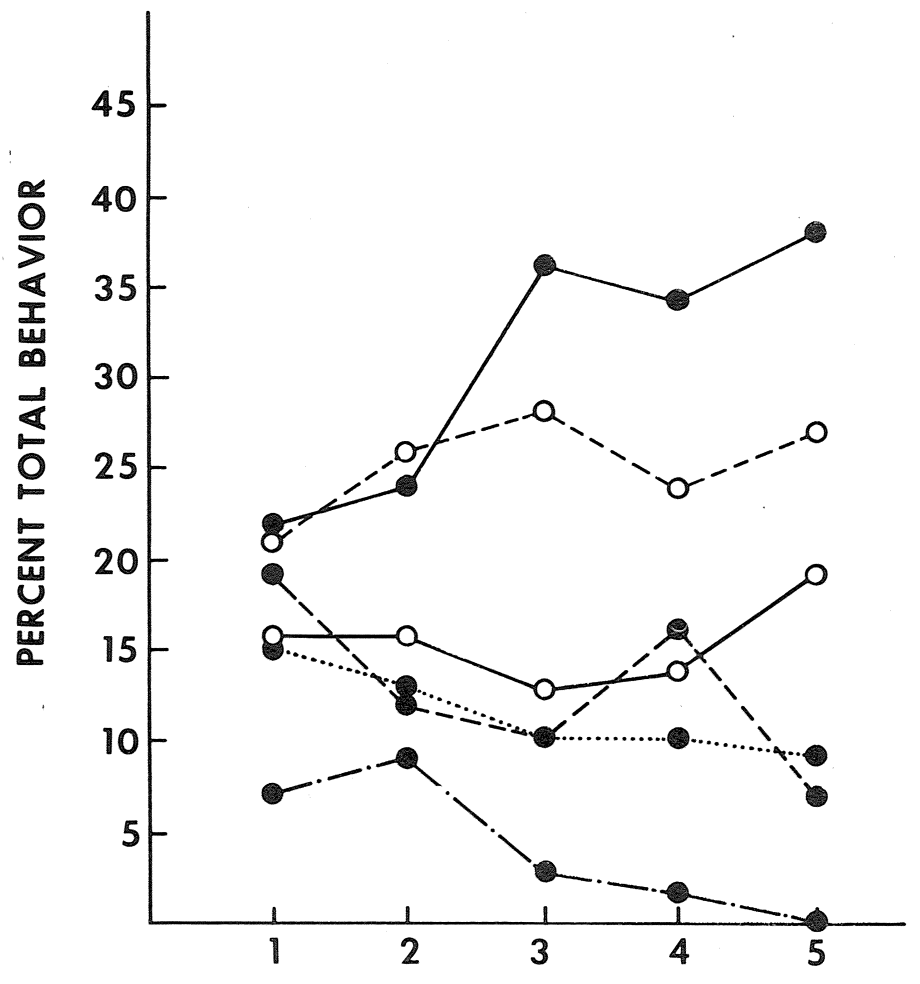

LEVEL

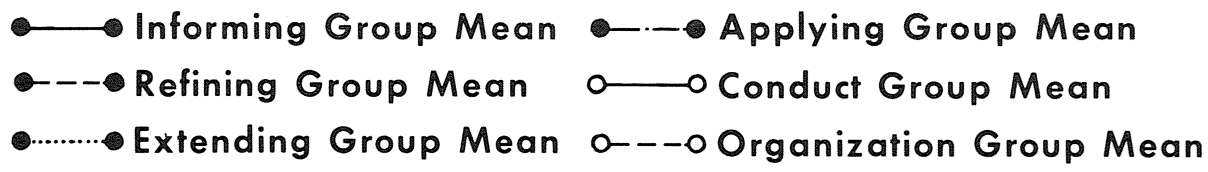

Figure 3. Percent of each Design Function -- All Tapes.

\section{Comparisons for Recipient/Characteristics of the Source}

A comparison of teacher verbal behaviors was made in terms of the audience to whom that behavior was addressed. Data are summarized in Tables $2 \mathrm{~A}$ and $2 \mathrm{~B}$, and represented in Figure 4. A trend emerged which depicted a steady increase in teacher verbal behavior directed to the class $\left(33^{\circ}\right.$ to $50^{\circ}$ ) and to individuals (18\% to $37 \%$ ). These increases were made possible by a decrease in communication with individuals in a non-private way (so the whole class might hear). The emerging trend reflected a tendency for students to begin their lessons with group instruction and to shift to individualization later in the lessons. Morgenegg (1977), found that 57\% of all physical education teachers' interactions were directed toward individuals, $26.8^{\circ}$ to the whole class, and $16.2^{\circ}$ toward groups. The results of this study represent a significant departure from those figures. 


\section{RECIPIENT/CHARACTERISTICS OF THE SOURCE}

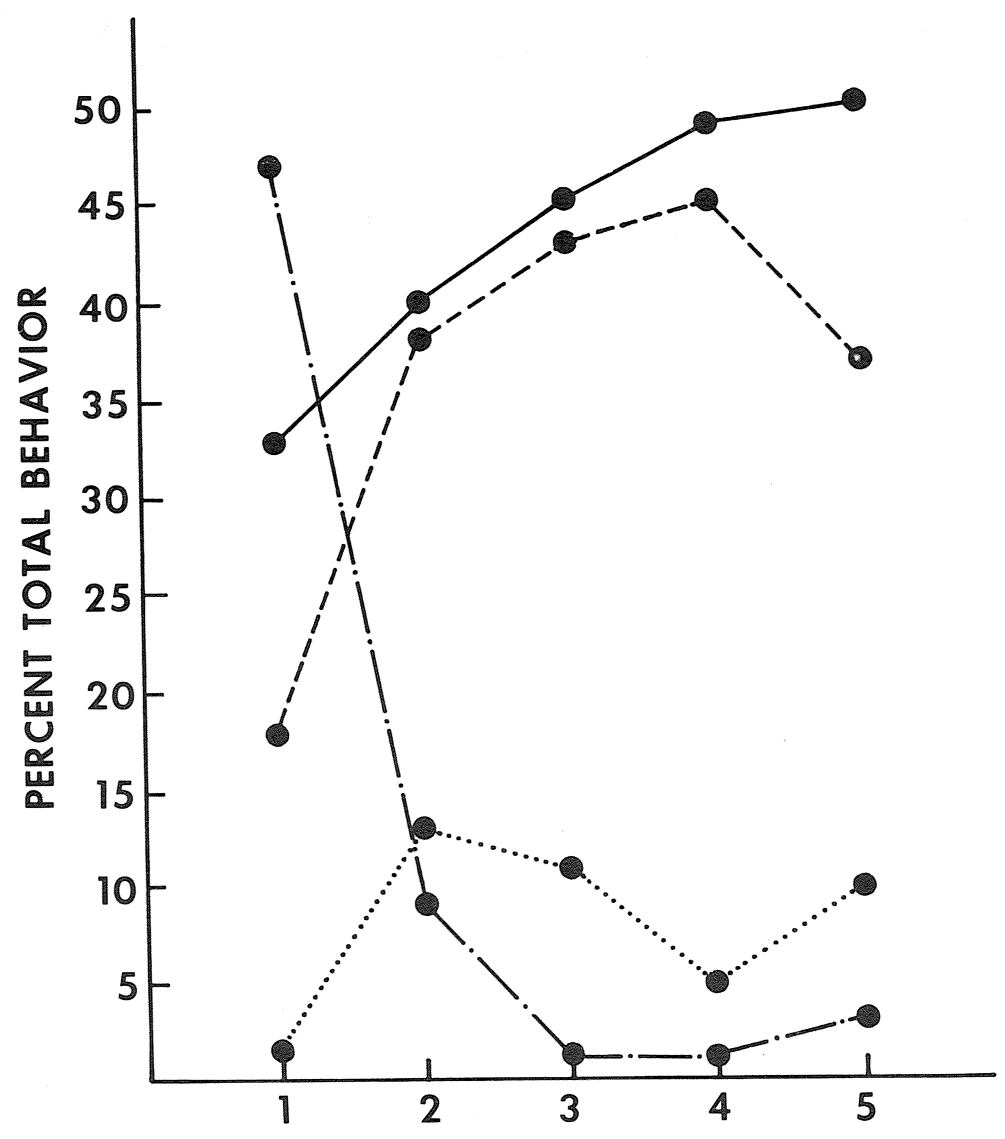

LEVEL

$\longrightarrow$ Class Group Mean

- - - Individual Group Mean
-........ Group Group Mean

-.-. Individual - Nonprivate Group Mean

Figure 4. Percent Recipient/Characteristics of the Source -- All Tapes. 


\section{Specific Appraisals}

Siedentop (1983) has suggested that precise feedback usually results in quicker and better learning. This ability to provide specific feedback has been identified as a desirable teacher behavior.

The verbal statements that directly and explicitly communicate a judgment about the behavior and motor performance of the children is reported in Tables $2 \mathrm{~A}$ and $2 \mathrm{~B}$. Figure 5 presents a display of specific appraising behavior.

\section{SPECIFIC APPRAISALS}

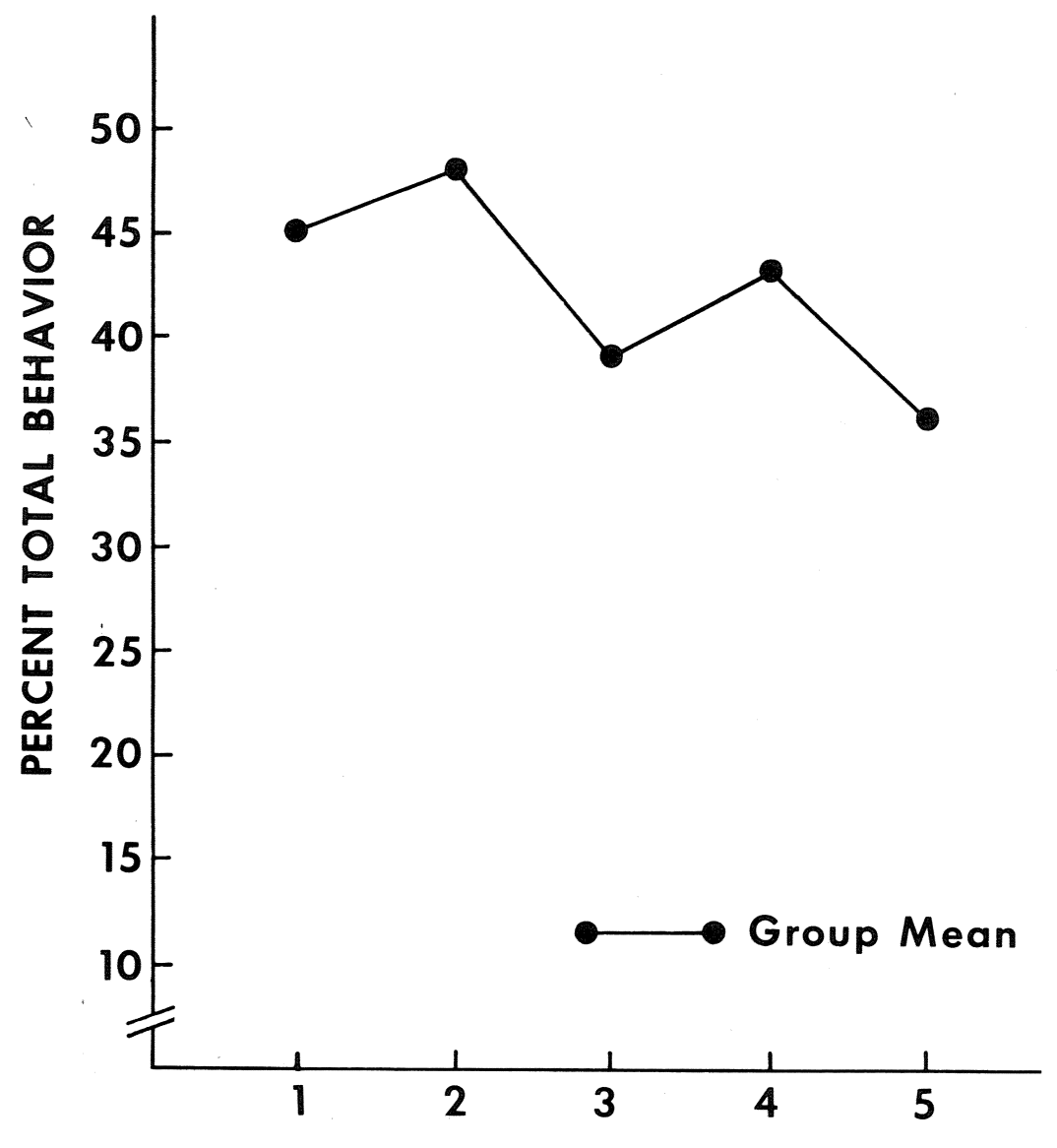

LEVEL

Figure 5. Percent Specific Appraisals -- All Tapes. 
A comparison of the specific appraisals of the pre-service teachers over the five field experiences revealed little variability. The data revealed that 58\% of the appraisals were general and $42 \%$ were specific. The findings showed improvement over the results of Anderson and Barrette (1978) who found $65^{\circ}$ general and $35^{\circ}$ specific.

Tobey (1974) also found that a large proportion of teacher judgments contained no appraisals. He suggested that specific appraisals required more effort and ability on the part of the teachers. His findings indicated that the more experienced the teachers became, the more judgments about performance were made. He also found that larger classes received less appraising feedback as compared to medium and smallsized classes. Similarly, the decline (45\% to $36 \%$ ) in specific appraisals in this study could be attributed to the increase in class size through the five levels. Since larger classes require a considerable amount of organizational skills, there may have been less opportunity for the pre-service teachers to provide specific appraisals related to performance.

\section{Comparisons for Activity Time}

The subjects conducted lessons in a manner that allowed for more pupil motor activity time than inactivity. Tables $2 \mathrm{~A}$ and $2 \mathrm{~B}$, along with Figure 6 depict the activity time. Data revealed that $53 \%$ to $67 \%$ of the class time was devoted to pupil motor activity. The findings in this study showed marked improvement in activity time over the results of Costello (1977). Costello found that elementary children spent $60^{\circ}$ of the total class time either waiting or listening to the teacher with less than one third of the time devoted to motor activity.

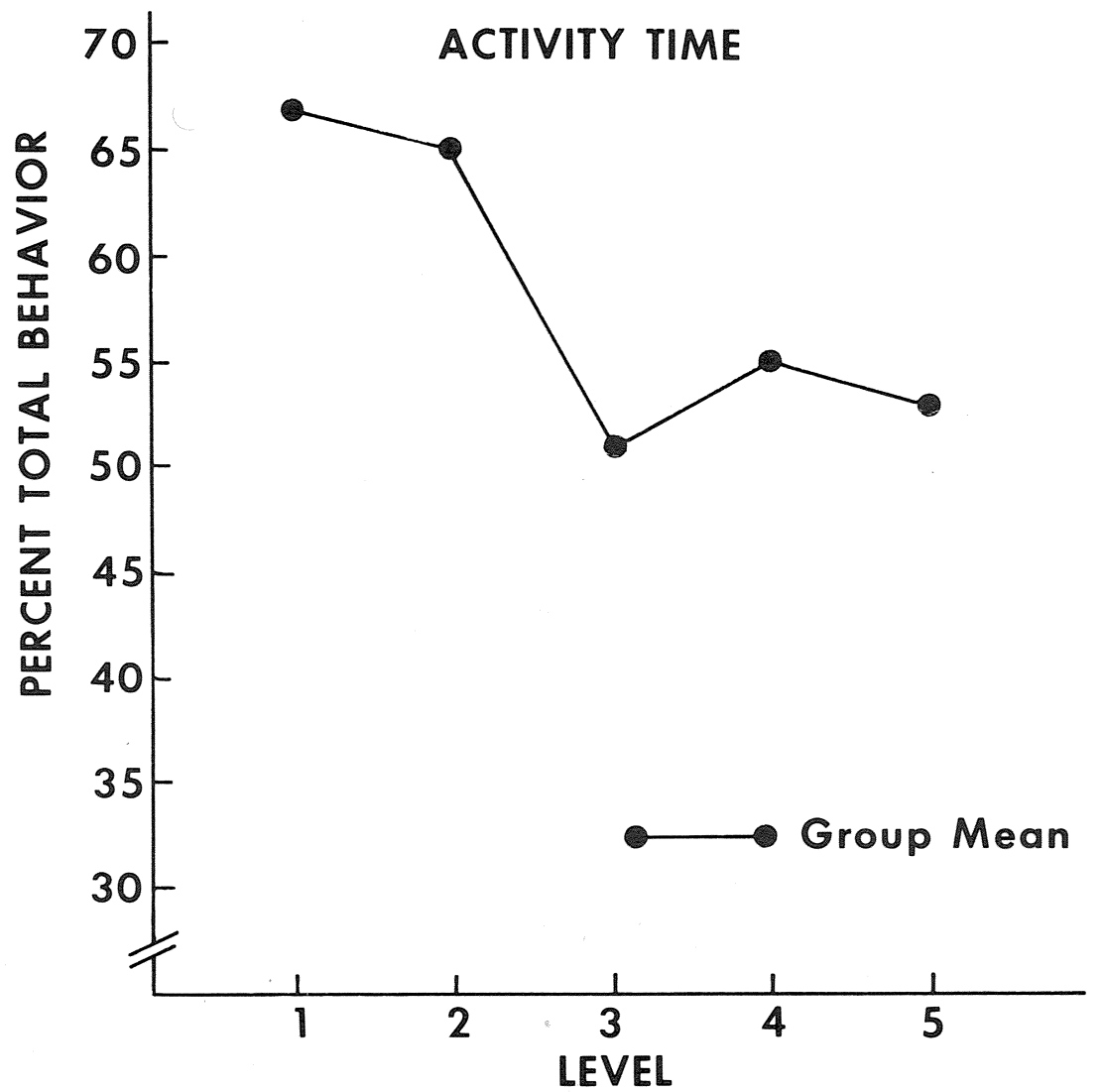

Figure 6. Percent Activity Time -- All Tapes. 
Various writings in the study of teacher effectiveness supported the belief that academic learning time (ALT) or involvement in on-task motor performance is important in the learning process (Siedentop, Birdwell \& Metzler, 1979; Graham \& Heimerer, 1980). While the results of the current study indicated that pupils spent a higher proportion of class time engaged in motor activity, there was a decline over the five levels from $67 \%$ to $53 \%$. The declining trend might be attributed in part to the increase in both informing types of communication and organized task presentations. Also, it might be attributed to the increase in class size and the fact that the subjects were responsible for the total period of instruction.

\section{Soliciting/Extending to Individual Pupils}

The communication function and the instructional design function both make a direct contribution to content development in physical education. The combination of these two categories forms the basis of OSCD-PE. Visual inspection of the observational records resulted in the identification of one additional teaching trend.

The behavior soliciting/extending was analyzed in terms of the recipient/characteristics of the source. Figure 7 shows the soliciting/extending behavior as it was applied to individual pupils. This behavior represents an attempt to modify or individualize lesson content for individuals during activity. Teachers in the first field experience devoted only $20 \%$ of the soliciting/extending to individual pupils; whereas, this behavior increased in the second field experience (43\%), the third field experience $(57 \%)$, the fourth $(52 \%)$, and culminated at a high frequency in the fifth $(60 \%)$ field experience. There was an increase of forty percentage points in soliciting/extending behavior directed towards individuals. This behavior represents the efforts of the teacher to change the task for individuals. It is a significant behavior in individualizing instruction. The results suggested that as the pre-service teachers became more experienced they put a greater emphasis on individual instruction. This practice was accompanied by a shift to more individual extending behavior over the five field experiences.

\section{Summary and Conclusions}

The results of this study reflect the efforts of one institution to use field experiences to develop the teaching skills of pre-service teachers. One interesting element was that high levels of desirable behaviors were achieved in the first teaching experiences (specific appraisals, positive reinforcement, low levels of management, high levels of activity time, refining behaviors and extending behaviors). Some of these were lost as the degree of monitoring of the field experiences decreased somewhat and as the number of children and time actually teaching increased. Most of these desirable behaviors were not lost, however, even though the complexity of the teaching environment increased significantly. The students in this study maintained higher levels of these desirable behaviors than previous descriptive studies of practicing teachers have reported.

There were some changes of practical importance in behavior from the beginning levels of experience to the later levels of experience. The iarget of behavior moved from work with individuals in a private way to work with the whole class. Verbal questioning and a more narrow soliciting of movement responses also showed a continuous increase. All of these behaviors reflect a move toward more direct instruction as described by Graham and Heimerer (1980). Accompanying these changes was a dramatic increase $\left(20^{\circ}\right.$ to $60^{\circ}$ ) in the ability of these students to modify tasks for individuals within a class during instruction. This change is considered a very positive indicator of teacher ability to individualize instruction.

The changes that reflect a decline in the pre-service teachers' ability to refine movement responses of students and manipulate the content by making it more difficult or easier (extend), were not considered desirable results and will undoubtedly become a program emphasis as a result of this study. 


\section{SOLICITING/EXTENDING}

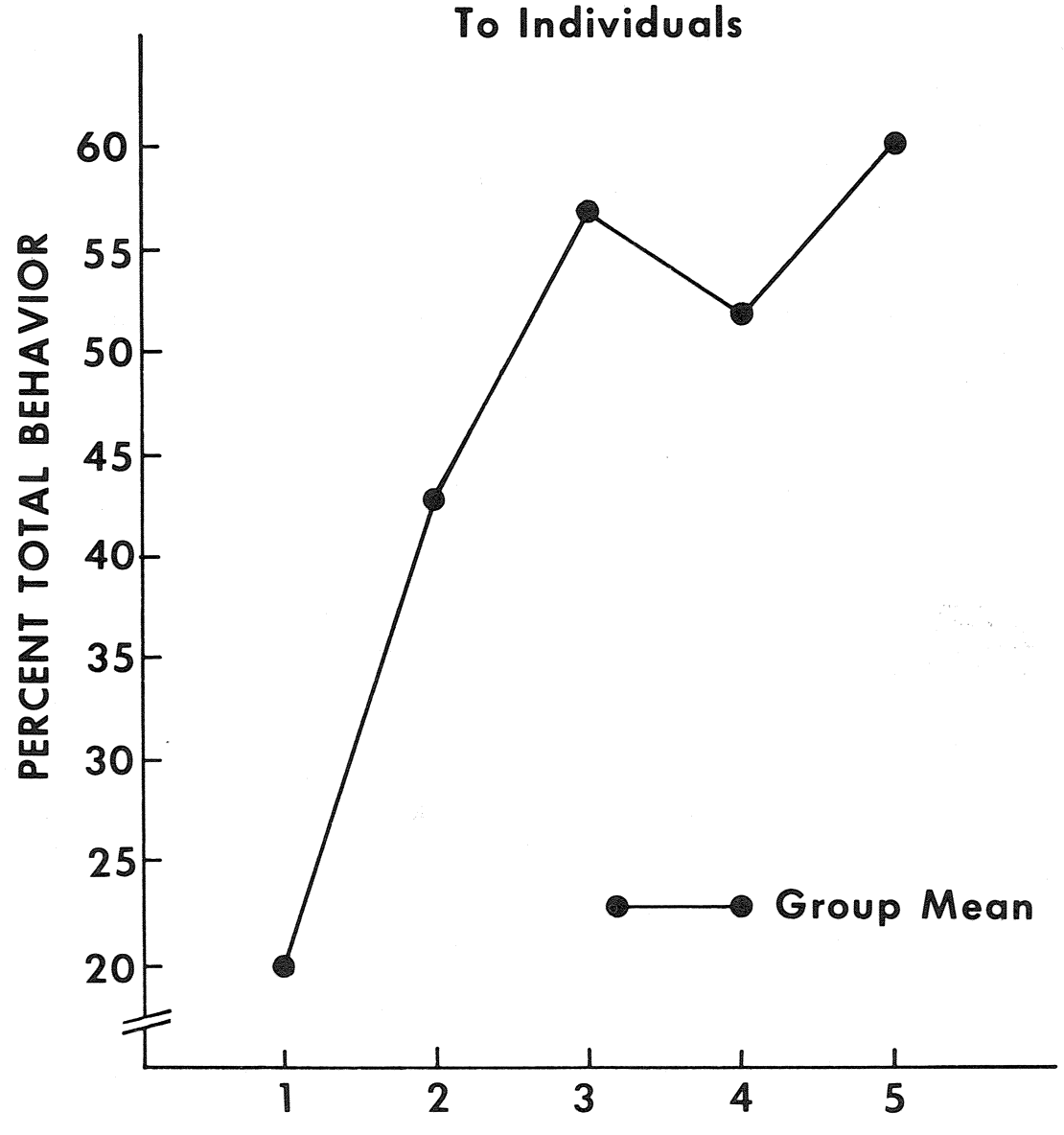

LEVEL

\section{Figure 7. Percent Soliciting/Extending Behavior Expressed to Individuals -- All Tapes.}

Most studies on change in pre-service teaching behavior have relied on behavior analysis techniques as a monitoring function either alone or in conjunction with other interventions irrespective of context (Rife, 1974; Boehm, 1974; Darst, 1974; Keilty, 1975). The intent of the current study was to describe the continuous development of pre-service teacher behavior of college students in a teacher preparation program. None of the pre-service teachers were trained in the descriptive instrument used in the study nor were they given feedback on the specific concepts of OSCD-PE. The college supervisors monitored the performance of the pre-service teachers in their regular manner. Lessons were planned and feedback provided prior to the lesson presentations. The college students were observed by the supervisor and situationspecific feedback was provided. 


\section{References}

Anderson, W. C., \& Barrette, G. T. (Eds.). What's going on in gym: Descriptive studies of physical education classes. Monograph 1, Motor Skills: Theory Into Practice, 1978.

Boehm, J. H. The effects of a competency based teaching program on junior high school physical education student teachers and their pupils. (Doctoral Dissertation, The Ohio State University, 1974). Ann Arbor, MI: University Microfilms No. 75-03013.

Costello, J. A. A descriptive analysis of student behavior in elementary school physical education classes. Unpublished Doctoral Dissertation, Teachers College, Columbia University, 1977.

Darst, P. W. The effects of competency based teacher education on student teacher and pupil behaviors. (Doctoral Dissertation, The Ohio State University, 1974). Ann Arbor, MI: University Microfilms No. 75-03044.

Graham, G., E Heimerer, E. Research on teacher effectiveness: Implications for the real world teacher. Paper presented at the National Conference at AAHPHERD, Detroit, April, 1980.

Keilty, G. C. The effects of instruction and supervision of interaction analysis of the preparation of student teachers. (Doctoral Dissertation, Boston University, 1975). Ann Arbor, MI: University Microfilms No. 75-5829.

Logsdon, B. J. et al. Physical education for children: A focus on the teaching process. Philadelphia, PA: Lea and Febiger, 1977.

Morgenegg, B. The pedagogical functions of physical education teachers. Unpublished Doctoral Dissertation, Teachers College, Columbia University. 1977.

Rife, F. N. Modification of student teacher behavior and its effect upon pupil behavior. (Doctoral Dissertation, The Ohio State University, 1973). Ann Arbor, MI: University Microfilms No. 74-03298.

Rink, J. E. The development of an observation system for content development in physical education. Unpublished Doctoral Dissertation, The Ohio State University, 1979.

Siedentop, D. Developing teaching skills in physical education. (2nd ed.). Palo Alto, CA: Mayfield Publishing, 1983.

Siedentop, D. The Ohio State University supervising research program summary report. Journal, of Teaching in Physical Education. Introductory Issue, 1981, 30-33.

Siedentop, D., Birdwell, D., \& Metzler, M. A process approach to measuring teaching effectiveness in physical education. The Ohio State University, 1978. (Mimeographed).

Tobey, C. A descriptive analysis of the occurrence of augmented feedback in physical education classes. (Doctoral Dissertation, Teachers College, Columbia University, 1974). Ann Arbor, MI: University Microfilms No. 74-26623. 